\title{
PENDUGAAN PARAMETER POPULASI IKAN CAKALANG (Katsuwonus pelamis, Linnaeus, 1758) DI SAMUDERA HINDIA SELATAN JAWA
}

\section{THE ESTIMATION ON POPULATION PARAMETERS OF SKIPJACK (Katsuwonus pelamis, Linnaeus, 1758) IN THE INDIAN OCEAN SOUTH OF JAVA}

\author{
Fathur Rochman, Budi Nugraha dan Arief Wujdi \\ Peneliti pada Loka Penelitian Perikanan Tuna, Benoa \\ Teregistrasi I tanggal: 16 April 2014; Diterima setelah perbaikan tanggal: 02 Juli 2015; \\ Disetujui terbit tanggal: 06 Juli 2015 \\ e-mail:fathursmasabio1@gmail.com
}

\begin{abstract}
ABSTRAK
Ikan cakalang (Katsuwonus pelamis) tergolong jenis ikan tuna yang merupakan tangkapan utama di Samudera Hindia. Kajian dinamika populasi menjadi penting sebagai dasar pengelolaan perikanan, agar stok ikan dapat dimanfaatkan secara berkelanjutan. Penelitian ini bertujuan untuk menyediakan informasi tentang parameter populasi ikan cakalang di perairan Samudera Hindia Selatan Jawa. Pengambilan data dengan bantuan enumerator di pusat pendaratan ikan (Cilacap, Palabuhanratu, Tamperan-Pacitan, dan Sendang biru-Malang) selama periode Januari-Desember 2012 dengan jumlah sample total sebanyak 3.118 ekor. Data frekuensi panjang (cmFL) selanjutnya dianalisis menggunakan program FiSAT II untuk menduga parameter pertumbuhan, mortalitas, dan rekrutmen. Hasil penelitian parameter populasi adalah sebagai berikut: panjang asimptotik (L.) sebesar 80,85 cmFL dengan nilai $\mathrm{K}$ sebesar 1,1/tahun dan nilai $\mathrm{t}_{0}$ sebesar $-0,110$ tahun. Mortalitas alami (M) sebesar 1,44/ tahun, mortalitas total (Z) sebesar 2,99/tahun dan mortalitas karena penangkapan (F) sebesar 1,55/tahun. Pola rekrutmen ikan cakalang terjadi setiap tahun dengan puncaknya diduga pada bulan April sampai dengan Agustus. Tingkat eksploitasi sebesar 0,52/tahun, menyebar pada level yang optimum.
\end{abstract}

KATA KUNCI: Parameter populasi, cakalang, Selatan Jawa

\section{ABSTRACT}

Skipjack (Katsuwonus pelamis) is a kind of tuna (tuna like species) which is the main cacth in Indian Ocean. Study of population parameters become important as a fisheries management base, so that fish stock could be utilized in a sustainable manner. The aims of this study is to provide information about population parameters of skipjack in Indian Ocean South of Java. The data were collected by Research Institute for Tuna Fisheries (LPPT) enumerators located at Cilacap, Palabuhanratu, Tamperan-Pacitan, dan Sendang biru-Malang. Data were collected from January to December 2012 with the total number of 3.118 sampled. The data of length frequency ( $\mathrm{cmFL}$ ) were analyzed using FiSAT II program to estimate the parameters of growth rate, mortality rate, and recruitment. The results showed that there were differences in the parameter of tuna populations related to environmental conditions due to the change of seasons. The population parameters of skipjack were as follow: length infinity $\left(L_{n}\right)=80.85 \mathrm{cmFL}$ with $K=1.10$ per year and $t_{0}=-0.110$ year. Natural mortality $(M)=$ 1.44 per year, total mortality $(Z)=2.99$ per year and fishing mortality $(F)=1.55$ per year. The skipjack recruitment pattern occurs in every year with peak performance in April until August. The Exploitation rates was 0.52 per year, spreaded in optimum level.

KEY WORDS: Population parameters, skipjack, South of Java

\section{PENDAHULUAN}

Menurut Anonimous (2014), penangkapan cakalang di Samudera Hindia mulai meningkat secara perlahan- lahan dari tahun 1950 sampai 2000. Pada tahun 1950 produksi ikan cakalang di Samudera Hindia sebesar 15.000 ton dan pada tahun 2013 menjadi 420.000 ton. Menurut Dueri et al. (2012), produksi ikan cakalang tertinggi di Samudera Hindia dicapai pada tahun 2006 sebesar 620.000 ton dan sejak saat itu hasil tangkapan ikan cakalang di Samudera Hindia tidak dapat melebihi jumlah tersebut. Peningkatan produksi terbesar terjadi pada periode tahun 1980-an yang Korespondensi penulis:

Loka Penelitian Perikanan Tuna

Jl. Mertasari No.140, Banjar Suwung Kangin, Sidakarya, Denpasar Selatan, Bali-80223 disebabkan oleh penggunaan pukat cincin yang dikombinasikan dengan rumpon oleh nelayan Prancis dan Spanyol. Sejak saat itu cakalang ditempatkan sebagai ikan tuna komersial penting di Samudera Hindia.

Menurut Dueri et al. (2012), disebutkan pula bahwa ikan cakalang (Katsuwonus pelamis), merupakan jenis ikan yang terdistribusi merata di Samudera Hindia. Ikan cakalang berimigrasi jarak jauh dan menempati perairan tropis maupun sub-tropis Arai et al. (2005) dan Nihira et al. (1996). Secara spatial dan temporal Keberadaan ikan ini sangat terkait dengan dinamika faktor lingkungan khususnya 
lokasi tempat mencari makan atau biasa disebut forage habitat (Andrade \& Garcia, 1999). Secara komersial ikan cakalang ditangkap dengan menggunakan pukat cincin (purse seine), jaring insang (gill net) dan pancing ulur (handline). Hasil tangkapan ikan cakalang adalah 50\% dari total tangkapan ikan tuna tropis (tropical tuna) di Samudera Hindia. Uktolseja et al. (1989) menyatakan bahwa penyebaran cakalang di perairan Indonesia meliputi Samudera Hindia (perairan Barat Sumatra, Selatan Jawa, Bali dan Nusa Tenggara), perairan Indonesia bagian timur (Laut Sulawesi, Maluku, Arafuru, Banda, Flores dan Selat Makassar) dan Samudera Pasifik.

Ikan cakalang (Katsuwonus pelamis), merupakan spesies yang bermigrasi luas (highly migratory species). Distribusi, pergerakan dan kerentanannya dipengaruhi oleh habitat yang disukainya. Keberadaan mangsa, temperature yang sesuai dan oksigen yang mencukupi sangat berpengaruh nyata terhadap kelangsungan hidup ikan cakalang. Sebagai konsekwensinya, distribusi spasial ikan cakalang bersifat musiman dan berpola tahunan (Mugo et al., 2010). Pengetahuan tentang populasi ikan merupakan dasar dalam analisis stok ikan. Informasi tersebut menjadi penting karena dapat digunakan sebagai alternatif masukan dalam pengambilan keputusan terkait perencanaan pengelolaan sumberdaya perikanan (Welcomme, 2001). Kajian terbaru tentang dinamika populasi ikan cakalang di Samudera Hindia perlu dilakukan untuk mengetahui kondisi parameter populasi dan perubahan yang terjadi pada populasi tersebut.

Tujuan penelitian ini adalah menyediakan informasi tentang parameter populasi ikan cakalang dari perairan Samudera Hindia yang meliputi panjang asimtot ( $\mathrm{L}_{\text {,) }}$, koefisien pertumbuhan $(\mathrm{K})$, umur teoritis $\left(\mathrm{t}_{0}\right)$, mortalitas alami (M), mortalitas total (Z), mortalitas akibat penangkapan $(F)$, pola rekrutmen dan laju eksploitasi (E).

\section{BAHANDANMETODE}

Penelitian didasarkan pada contoh ikan hasil tangkapan pukat cincin (purse seine), jaring insang (gill net), rawai tuna (longline) dan pancing ulur (handline) yang didaratkan melalui pelabuhan perikanan di Cilacap, Palabuhanratu, Pacitan dan Sendang Biru (Gambar 1).

Pengambilan data dilakukan dengan bantuan tenaga enumerator pada bulan Januari - Desember 2012 dengan menggunakan metode sampling acak.

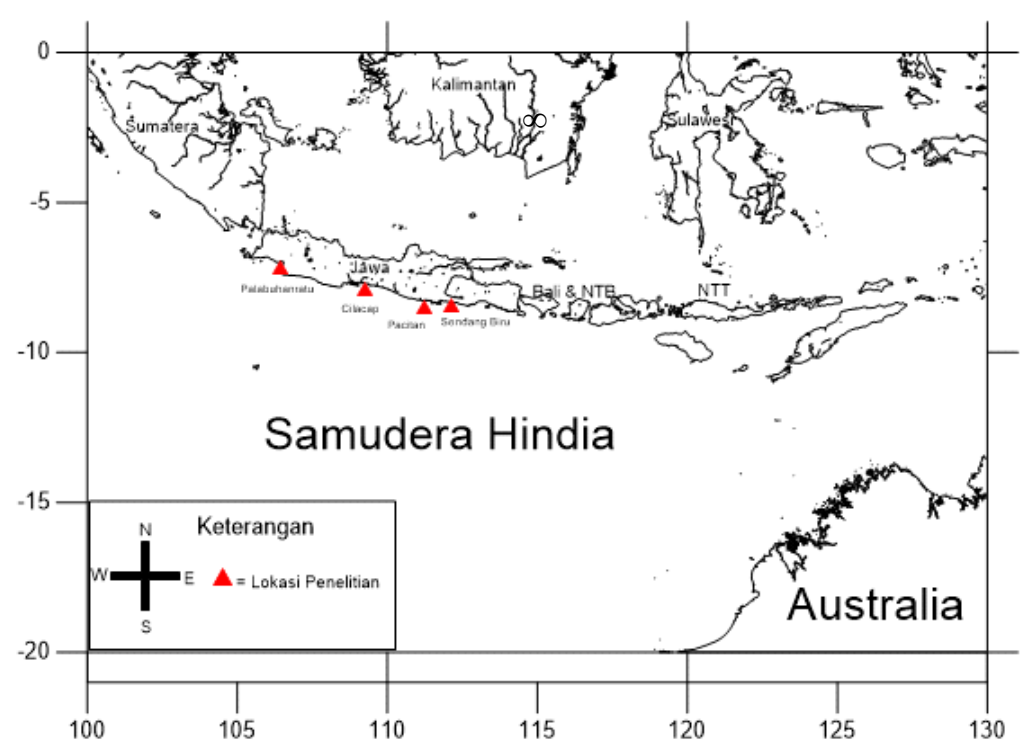

Gambar 1. Peta lokasi penelitian di Samudera Hindia Selatan Jawa.

Figure 1. Map showing research location in Indian Ocean South of Java.

Data pengukuran ikan dilakukan oleh enumerator secara time series. Pengukuran terhadap panjang cagak (fork length) ikan cakalang menggunakan kaliper dengan ketelitian $0.5 \mathrm{~cm}$. Data panjang ikan yang diperoleh, kemudian ditabulasikan dalam bentuk tabel distribusi frekuensi panjang dengan interval $3 \mathrm{~cm}$.

Parameter Pertumbuhan ikan (K \& L $\infty$ ) dianalisis dengan menggunakan perangkat lunak ELEFAN I (Gayanilo et al.,
2005) berdasarkan persamaan pertumbuhan Von Bertalanfy (Sparre \& Venema, 1999; Effendie, 2002) sebagai berikut:

$\mathrm{Lt}=\mathrm{L} \infty\left(1-\mathrm{e}^{-\mathrm{K}(\mathrm{t}-\mathrm{o})}\right)$

dimana:

$\mathrm{Lt}=$ panjang teoritis ikan pada umur tertentu

$\mathrm{L}^{\infty}=$ panjang asimtotik

$\mathrm{K}=$ koeffisien pertumbuhan 
$\mathrm{t}=$ umur teoritis ikan

$\mathrm{t}_{0}=$ umur teoritis ikan pada panjang ke nol

Umur teoritis $\left(\mathrm{t}_{0}\right)$ dihitung menggunakan persamaan empiris Pauly (1983) sebagai berikut:

$\log -\left(t_{0}\right)=-0,3922-0,2752 \log L_{\infty} 1,038 \log K$

Mortalitas alami ikan (M) diduga dengan menggunakan rumus empiris Pauly (1983) sebagai berikut:

$\log M=-0,0066-0,279 \log +0,654 \log K+0,4534 \log$

Dimana:

M = laju kematian alamiah

$\mathrm{L}=$ panjang cagak ikan maksimum $(\mathrm{cm})$

$\mathrm{K}=$ laju pertumbuhan ( $\mathrm{cm} /$ tahun)

$\mathrm{T}=$ suhu rata-rata $\left({ }^{\circ} \mathrm{C}\right)$

Laju kematian total (Z) diduga melalui kurva konversi hasil tangkapan (catch curve) yang menggunakan slope (b), Ln N/t dan umur relatif sesuai dengan rumus (Pauly,1983 \& Gayanilo et al., 2005) sebagai berikut:

$\operatorname{Ln} \mathrm{N} / \mathrm{t}=\mathrm{a}-\mathrm{Zt}$

dimana:

$\mathrm{N}=$ banyaknya ikan madidihang pada waktu ke- $\mathrm{t}$

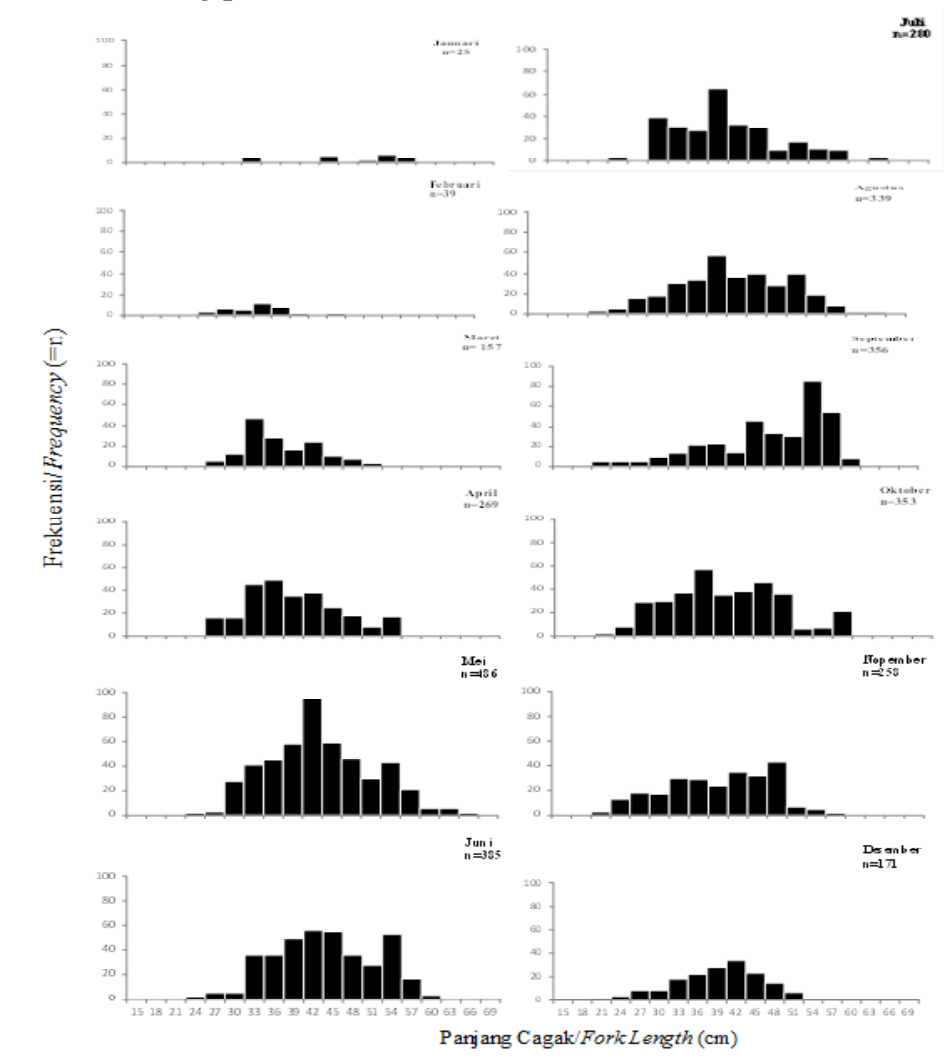

Gambar 2. Distribusi frekuensi panjang cagak ikan cakalang (Katsuwonus pelamis) yang tertangkap di Samudera Hindia Selatan Jawa secara bulanan.

Figure 2. Monthly fork length frequency distribution of skipjack (Katsuwonus pelamis) caught in Indian Ocean

South of Java. $\mathrm{t}=$ waktu yang diperlukan untuk tumbuh suatu kelas panjang

$\mathrm{a}=$ hasil tangkapan yang dikonversikan terhadap panjang

Laju kematian karena penangkapan (F) diperoleh dengan cara mengurangi laju kematian total $(\mathrm{Z})$ dengan laju kematian alamiah (M) atau $\mathrm{F}=\mathrm{Z}-\mathrm{M}$. Laju pengusahaan (E) dihitung sebagai E=F/Z (Sparre \& Venema, 1999). Panjang pertama kali ikan tertangkap (Lc) didapatkan dengan cara memplotkan frekuensi kumulatif dengan setiap panjang cagak ikan, sehingga akan diperoleh kurva logistik baku. Titik potong antara kurva dengan 50\% frekuensi kumulatif menunjukkan panjang saat $50 \%$ ikan tertangkap.

\section{HASIL DAN PEMBAHASAN \\ HASIL}

\section{Struktur Ukuran dan Panjang Pertama Kali Tertangkap}

Pengukuran panjang cagak ikan cakalang (Katsuwonus pelamis) secara acak ditempat pendaratan ikan dilakukan terhadap 3.118 ekor ikan. Ukuran panjang cagak berkisar antara 20-65 cmFL. Sebaran frekuensi panjang cagak tiap bulannya ditampilkan pada Gambar 2. 
Gambar 2 menunjukkan bahwa pada bulan Februari sampai dengan bulan Juni, struktur ukuran ikan cakalang mengalami pergerakan modus panjang ke arah kanan secara signifikan. Hal ini menandakan bahwa populasi ikan cakalang di Samudera Hindia Selatan Jawa mengalami pertumbuhan. Demikian juga antara bulan Juli sampai dengan Desember terjadi pergeseran modus kearah kanan pula namun terjadi pada kohor yang berbeda. Hal ini menandakan bahwa ikan cakalang mengalami pertumbuhan yang cepat.

Panjang ikan cakalang pertama kali tertangkap $\left(\mathrm{L}_{c}\right)$, diperoleh sebesar 38,73 cmFL (Gambar 3). Pengukuran ini merupakan hal yang penting untuk dipelajari dan dapat dihubungkan dengan panjang pertama kali matang gonad $\left(\mathrm{L}_{\mathrm{m}}\right)$.

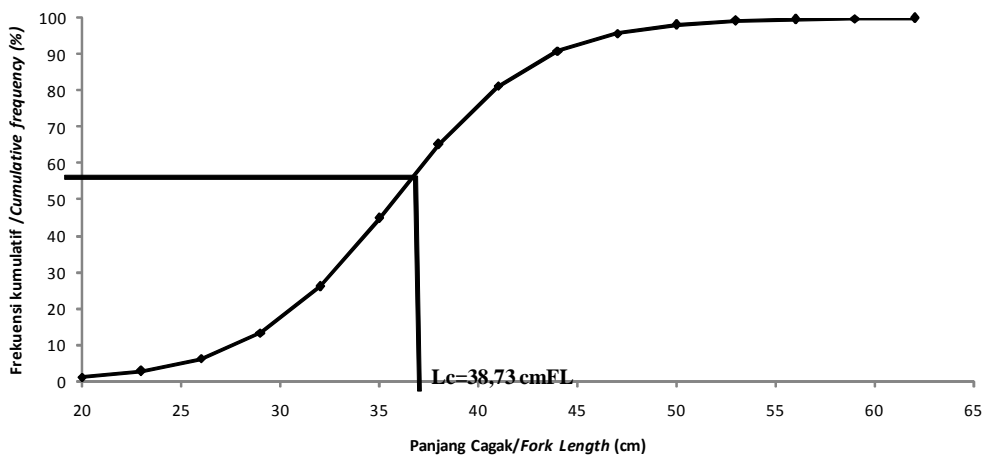

Gambar 3. Panjang pertama kali tertangkap ikan cakalang (Katsuwonus pelamis) yang tertangkap di Samudera Hindia Selatan Jawa.

Figure 3. Length at the first capture of skipjack (Katsuwonus pelamis) caught in Indian Ocean South of Java.

\section{Parameter Pertumbuhan}

Berdasarkan persamaan Von Bertalanffy yang dikombinasikan dengan rumus Pauly (1983) diperoleh nilai dugaan panjang asimptotik $\left(\mathrm{L}_{\text {,) }}\right.$ ) sebesar 80,85 cmFL, koefisien pertumbuhan $(\mathrm{K})$ sebesar 1,1/tahun dan umur teoritis ikan pada panjang ke nol $\left(\mathrm{t}_{0}\right)$ sebesar $-0,110$. Dari hasil tersebut diperoleh persamaan pertumbuhan $\mathrm{L}_{\mathrm{t}}=80,85\left(1-\mathrm{e}^{-1.100(\mathrm{t}-(-0.110)}\right)$.

Berdasarkan parameter pertumbuhan diatas maka, diperoleh kurva laju pertumbuhan Von Bertalanffy ikan cakalang sebagai berikut:

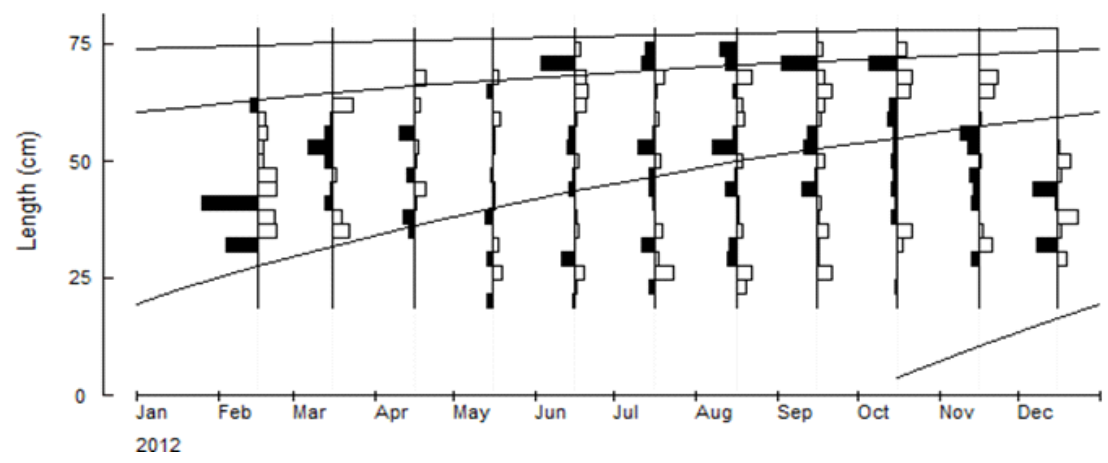

Gambar 4. Kurva laju pertumbuhan Von Bertalanffy ikan cakalang (Katsuwonus pelamis) di Samudera Hindia Selatan Jawa.

Figure 4. The Von Bertalanffy growth curve of skipjack (Katsuwonus pelamis) in Indian Ocean South off Java.

Dari dugaan persamaan laju pertumbuhan diatas, dapat dibuat hubungan antara umur dengan panjang tubuh cakalang. Kurva pertumbuhan cakalang yang pada tahun 2012 disajikan pada (Gambar 5).

\section{Pola Rekrutmen}

Berdasarkan nilai-nilai parameter pertumbuhan ikan cakalang yang dianalisis dengan subprogram Recruitment Pattern dalam program FiSAT II, dapat dilihat pola rekrutmen ikan tersebut untuk tiap tahunnya sebagaimana disajikan pada (Gambar 6).

\section{Mortalitas dan Laju Eksploitasi}

Mortalitas untuk populasi ikan yang sudah terekploitasi merupakan kombinasi antara mortalitas alami dan mortalitas karena penangkapan (Pauly, 1983; Sparre \& Venema, 1999; Welcomme, 2001). 


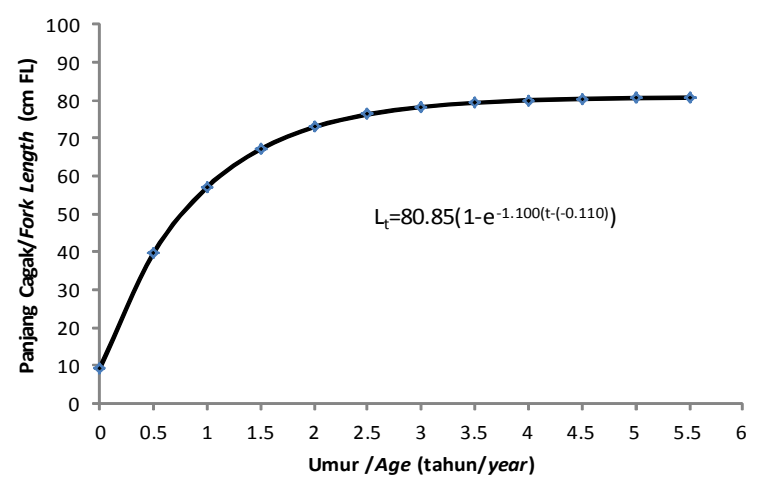

Gambar 5. Kurva pertumbuhan ikan cakalang (Katsuwonus pelamis) pada umur yang berbeda.

Figure 5. Growth curve at different ages of Skipjack (Katsuwonus pelamis).

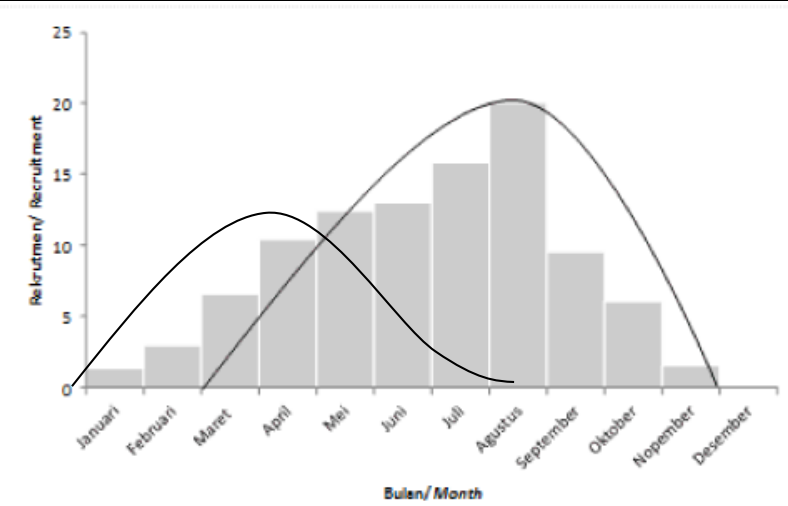

Gambar 6. Pola rekrutmen ikan cakalang di Samudera Hindia Selatan Jawa.

Figure 6. The skipjack recruitment pattern in Indian Ocean South of Java.

Mortalitas alami (M) dapat dihitung berdasarkan rumus empiris Pauly (1983) menggunakan data parameter pertumbuhan ikan dan rata-rata suhu permukaan air tahunan. Dalam hal ini rata-rata suhu tahunan Samudera Hindia Selatan Jawa sebesar $28^{\circ} \mathrm{C}$ (Martono et al., 1997). Hasil perhitungan menunjukkan nilai $\mathrm{M}$ ikan cakalang sebesar 1.44/tahun.
Mortalitas total (Z) dihitung dari kurva konversi hasil tangkapan dengan panjang (length converted cacth curve) dengan koefisien nilai slope negative (-b) yang diperoleh dari plot logaritma contoh ikan (ln N) dengan umur (t) (Pauly, 1983). Hasil perhitungan nilai $\mathrm{Z}$ dengan menggunakan plot length converted cacth curve menunjukkan nilai $\mathrm{Z}$ yang berbeda antar waktu. Dari analisis diperoleh nilai $\mathrm{Z}$ sebesar 2,99/tahun (Gambar 7).

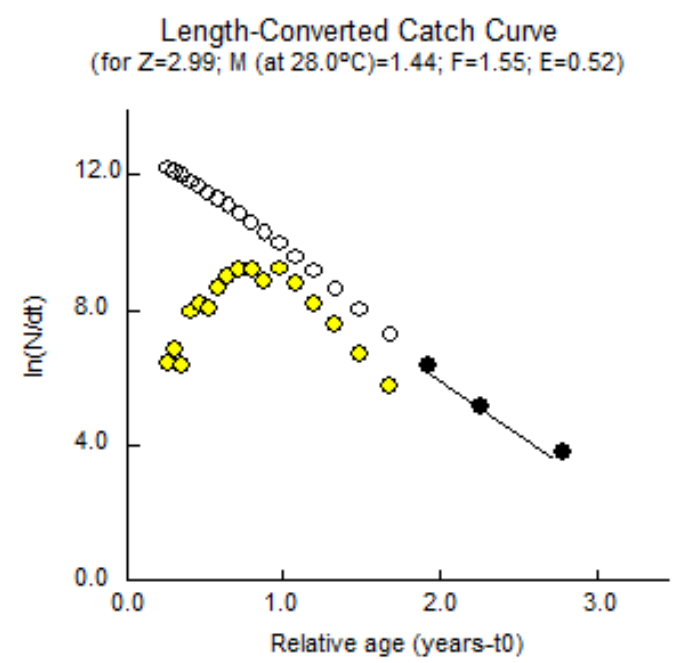

Gambar7. Nilai Z sebagai slope kurva hasil tangkapan ikan cakalang (Katsuwonus pelamis) di Samudera Hindia Selatan Jawa

Figure 7. The value of total mortality (Z) as a slope of catch curve of skipjack (Katsuwonus pelamis) in Indian Ocean South of Java. 
Hubungan antara mortalitas total (Z), mortalitas alami (M), mortalitas akibat penangkapan (F) dan laju eksploitasi (E) yang dihitung dengan persamaan Pauly (1983). Dari persamaan tersebut diperoleh nilai Mortalitas alami (M) sebesar 1.44/tahun, nilai mortalitas akibat penangkapan (F) sebesar 1.55/ tahun dan nilai laju eksploitasi (E) sebesar $0.52 /$ tahun.

\section{BAHASAN}

\section{Struktur Ukuran dan Panjang Pertama Kali Tertangkap}

Sebaran frekuensi ukuran panjang ikan cakalang tiap tahunnya, menunjukkan dua kelas modus yang berdistribusi normal. Berdasarkan analisis gerak maju modus dengan metode Bhattacharya dalam paket program FiSAT II (Gayanilo et al., 2005) dapat diketahui bahwa masing-masing sampel ikan cakalang terdiri atas 2 kelompok umur (kohort). Adanya kelompok umur yang berbeda menyatakan generasi ikan yang berbeda yaitu kelompok umur ikan muda dan dewasa (Nasution, 2009). Struktur umur masing-masing populasi ikan. tergantung dari mortalitas masing-masing kohort. Struktur umur juga menggambarkan kestabilan populasi ikan pada suatu perairan (Effendie, 2002). Ukuran panjang terbesar pada distribusi nilai tengah panjang cagak ikan cakalang terdapat pada panjang $53 \mathrm{cmFL}$ dengan frekuensi kejadian $15.06 \%$.

Berdasarakan hasil perhitungan panjang pertama kali ikan tertangkap $\left(\mathrm{L}_{\mathrm{c}}\right)$ diperoleh nilai $38,73 \mathrm{cmFL}$. Nilai tersebut masih berada di bawah nilai pertama kali matang gonad $\left(\mathrm{L}_{50}\right)$ yang besarnya antara 41-43 cmFL Samudera Hindia (Anonymous, 2014), $43 \mathrm{cmFL}$ di perairan barat dan selatan Maluku Utara (Karman et al., 2014), 49.30 cmFL di perairan Bitung Sulawesi Utara (Nugraha \& Rahmat, 2008) dan $48.09 \mathrm{cmFL}$ di perairan Flores Nusa Tenggara Timur
(Mallawa et al., 2014). Kesimpulan yang diperoleh bahwa ikan cakalang yang tertangkap di Samudera Hindia Selatan Jawa sebagian belum mencapai matang gonad. Disamping itu selektifitas alat tangkap untuk menangkap ikan cakalang yang matang gonad belum optimal.

\section{Parameter Pertumbuhan}

Ikan cakalang mempunyai panjang asimtotik (L,) sebesar 80,85 cmFL. Pauly (1983) menyatakan bahwa nilai L, berhubungan dengan ukuran panjang maksimum contoh ikan $\left(\mathrm{L}_{\max }\right.$ ) yang diperoleh selama kegiatan sampling. Nilai $\mathrm{L}_{\text {max }}$ yang diperoleh selama pengambilan contoh adalah $77 \mathrm{cmFL}$. Nilai tersebut tidak memiliki selisih yang cukup jauh dengan $95 \%$ L., berada pada kisaran jarak $3 \mathrm{cmFL}$. Hal tersebut menunjukkan bahwa kondisi habitat perairan Samudera Hindia sebagai fishing ground ikan cakalang cukup baik untuk perkembangbiakan ikan cakalang dengan kualitas air dan ketersediaan pakan alami yang melimpah sehingga ikan cakalang mampu bertahan dan memiliki panjang sampai maksimum.

Secara umum, nilai L, ikan cakalang yang didaratkan di Samudera Hindia Selatan Jawa pada periode penelitian mempunyai nilai yang berbeda jika dibandingkan dengan data penelitian sebelumnya di Samudera Hindia dengan menggunakan metode tagging pada tahun 2008 dengan $\mathrm{L}$, sebesar $73 \mathrm{cmFL}$ dengan nilai $\mathrm{K}$ sebesar 0,4 /tahun (Fontenau \& Gascuel, 2008), cakalang metode frekuensi panjang di teluk Bone dengan L, sebesar $75.90 \mathrm{cmFL}$ (Jamal et al., 2011). Perbedaan tersebut akibat adanya perbedaan lingkungan perairan dari waktu ke waktu. Ketersediaan pakan yang melimpah akan menyediakan energi yang cukup untuk pertumbuhannya, sehingga laju pertumbuhannya relative lebih cepat. Perbedaan tersebut tampak nyata dari hasil penelitian ikan cakalang sebelumnya di Samudera Hindia (Tabel 1).

Tabel 1. Estimasi parameter pertumbuhan ikan cakalang di beberapa lokasi di Samudera Hindia.

Table 1. Estimates of growth parameters for skipjack in another part of Indian Ocean.

\begin{tabular}{|c|c|c|c|c|}
\hline Lokasi/Location & $\mathrm{cm}$ & (tahun $\left.^{-1}\right)$ & Metode/Methods & Sumber/Refference \\
\hline Indian Ocean & 60,60 & 0,930 & Length-Frequency & Marcille \& Stequert,1976 \\
\hline Indian Ocean Maldives & 64,30 & 0,550 & Tagging & Adams, 1999 \\
\hline Indian Ocean Maldives & 82,00 & 0,450 & Length-Frequency & Hafiz, 1987, in Adams 1999 \\
\hline Indian Ocean Sri Langka & 85,00 & 0,620 & Length-Frequency & Amarasiri \& Joseph, 1987 \\
\hline Indian Ocean Sri Langka & 77,00 & 0,520 & Length-Frequency & Suvasubramaniam, 1985; in Adams, 1999 \\
\hline Indian Ocean Minicoy & 90,00 & 0,490 & Length-Frequency & Mohan \& Kunhikoya, 1985 in Adams, 1999 \\
\hline Indian Ocean Indonesia & 80,85 & 1,1 & Length-Frequency & Rochman et al., 2014 \\
\hline Sur
\end{tabular}

Sumber (source): J. P. Hallier \& D. Gaertner (2006); Gaertner et al. (2008)

Nilai K menunjukkan kecepatan suatu individu ikan untuk mencapai ukuran panjang asimtot $\left(\mathrm{L}_{\text {,.) }}\right.$, sehingga semakin besar nilai K maka semakin cepat nilai L., dicapai atau semakin pendek umur ikan (Nasution, 2009). Nilai K ikan cakalang yang diestimasi menunjukkan perbedaan yang fluktuatif. Pada tahun 2012, ikan cakalang memiliki nilai $\mathrm{K}=1,10$ (/tahun). Perbedaan nilai $\mathrm{K}$ tersebut dipengaruhi oleh faktor kondisi lingkungan, terutama 
suhu dan ketersediaan makanan. Sparre \& Venema (1999) menyatakan kecepatan pertumbuhan ikan tidak memiliki nilai yang mutlak dan bersifat dinamis terkait dengan tahap perkembangan hidup, laju metabolik dan kondisi lingkungan. Anderson \& Gutreuter (1983) menambahkan bahwa ikan tetap mengalami pertambahan panjang, bahkan dalam kondisi faktor lingkungan yang tidak mendukung.

Parameter umur pada saat di awal populasi $\left(\mathrm{t}_{0}\right)$ adalah umur teoritis ikan pada saat panjangnya $0 \mathrm{~cm}$. Nilai $\mathrm{t}_{0}$ dipengaruhi oleh nilai $\mathrm{L}_{\text {, }}$ dan nilai $\mathrm{K}$ seperti ditunjukkan pada persamaan empiris Pauly (1983). Nilai $t_{0}$ biasanya memiliki nilai kecil (biasanya negatif) dan berfungsi sebagai skala pada kurva pertumbuhan (King, 1995). Sparre \& Venema (1999) menyatakan bahwa nilai t tidak memiliki arti secara biologi, sebab pertumbuhan ikan dimulai saat telur menetas ketika larva ikan telah memiliki suatu panjang tertentu. Nilai $t_{0}$ memiliki peranan yang penting dalam pengelolaan perikanan, sebab nilai $t_{0}$ digunakan untuk menduga perkembangan folikel oosit tingkat akhir hingga oviposisi dan saat pemijahan. Keberhasilan pemijahan menentukan kekuatan rekrutmen individu baru kedalam stok.

\section{Pola Rekrutmen}

Pola rekrutmen cakalang setiap tahun menunjukkan 2 pulsa (modus) yang saling tumpang tindih (overlapping) dengan puncak rekrutmen dari bulan April dan Agustus. Hal itu diduga akibat perilaku ikan cakalang yang melakukan pemijahan secara sebagian (partial spawner). Secara umum, pola rekrutmen ikan cakalang tiap tahun tidak jauh berbeda dengan puncak rekrutmen yang mulai terjadi sekitar bulan April dan Agustus.

Pola rekrutmen terkait dengan waktu pemijahan (Ongkers, 2006). Puncak rekrutmen ikan cakalang terjadi pada bulan April (10,42\%) dan Agustus (20,06\%). Hal itu diduga akibat bergesernya musim pemijahan ikan cakalang yang ditandai dengan kemunculan individu baru dari hasil pemijahan pada bulan Oktober (Gambar 4). Pemijahan ikan ini kemungkinan juga dipengaruhi oleh pergeseran permulaan musim kemarau dan musim hujan akibat efek $E l$ Nino Southern Oscillation (ENSO). Pola rekrutmen yang diduga dengan program FiSAT seringkali tidak sesuai dengan kenyataan di alam. Model tersebut didasarkan pada dua asumsi yang jarang terjadi dalam kenyataan, yaitu semua sampel ikan tumbuh dengan satu set tunggal parameter pertumbuhan dan satu bulan dalam setahun selalu terdapat nol rekrutmen (Pauly, 1987; Gayanilo et al., 2005). Walaupun demikian, model yang dirunut dengan FiSAT bermanfaat untuk menduga bagaimana rekrutmen populasi ikan dialam terjadi dalam satu tahun.

Menurut Fontenau (2003), ikan cakalang memijah pada kisaran panjang antara 40-45 cm dan berumur kurang lebih satu tahun. Proses pemijahan terjadi pada suhu lebih dari $24^{\circ} \mathrm{C}$. Stequert \& Ramcharrun (1996) menyatakan bahwa ikan cakalang di Samudera Hindia mempunyai aktivitas pemijahan yang permanen dengan dua puncak musim pemijahan yaitu selama musim angin barat laut (NopemberMaret) dan musim angin tenggara (Juni-Agustus). Pemijahan ini menghasilkan rekrutmen yang berkesinambungan. Perbedaan nilai persentase rekrutmen relatif tiap bulannya pada tahun 2012 diduga terjadi akibat adanya pergeseran musim pancaroba dan akibat perubahan iklim atau anomali cuaca oleh faktor lainnya seperti pengaruh El Nino Southern Oscillation (ENSO).

\section{Mortalitas dan Laju Eksploitasi}

Mortalitas ikan cakalang yang telah dieksploitasi disebabkan oleh kombinasi antara mortalitas alami (M) dan mortalitas akibat penangkapan $(\mathrm{F})$. Diperoleh nilai $\mathrm{F}$ sebesar 1,55/tahun dengan laju eksploitasi (E) sebesar 0,52 /tahun. Secara umum mortalitas alami lebih rendah dari mortalitas akibat penangkapan. Laju eksploitasi optimum terjadi jika terdapat keseimbangan rasio antara $\mathrm{M}$ dan $\mathrm{F}$, sehingga diasumsikan bahwa nilai eksploitasi optimum $\left(\mathrm{E}_{\text {opt. }}\right)$ yang lestari setara dengan $\mathrm{E}=0,50$ (Gulland, 1971). Dilihat dari nilai E sebesar 0.52/tahun, diasumsikan bahwa tekanan eksploitasi ikan cakalang di Samudera Hindia Selatan Jawa, Bali dan Nusa Tenggara masih dalam kondisi optimum.

Anonymous (2012) menjelaskan bahwa produksi ikan cakalang pada tahun 2011 sebesar 398.000 ton. Rata-rata penangkapan dari tahun 2007-2011 sebesar 436.000 ton dan nilai Maximum Sustainable Yield (MSY) sebesar 478.000 ton. Mortalitas akibat penangkapan (F) sebesar 1,2/tahun dengan ( $F_{\text {MSY }}$ ) 1,5/tahun. Dari informasi tersebut, diketahui bahwa nilai mortalitas akibat penangkapan (F) di Samudera Hindia Selatan Jawa telah melampaui nilai $\mathrm{F}_{\mathrm{MSY}}$ hasil penelitian Anonymous (2012) sehingga pendekatan kehati-hatian tetap perlu diterapkan agar fenomena tangkap lebih (overfishing) tidak terjadi. Estimasi nilai E bersifat relatif sehingga dapat bersifat overestimate maupun underestimate, namun nilai tersebut dapat menjadi gambaran umum mengenai eksploitasi ikan cakalang di Samudera Hindia selatan Jawa, Bali dan Nusa Tenggara.

Menurut Fontenau (2003), ikan cakalang merupakan jenis khusus ikan tuna tuna like species dengan pergerakan migrasi yang terbatas. Penelitian dengan metode tagging, mengemukakan bahwa ikan cakalang mempunyai luas jangkauan migrasi (coverage area) kurang dari $1.500 \mathrm{mil}^{2}$ atau $2.778 \mathrm{~km}^{2}$. Sehingga, kondisi overfishing ikan cakalang bersifat lokal dan ditandai dengan penurunan ukuran (panjang dan berat) ikan dan penurunan jumlah tangkapan per satuan usaha (cacth per unit effort, CPUE). 
Pengelolaan perikanan pada dasarnya bertujuan agar keberadaan sumberdaya ikan tetap lestari dan berkelanjutan. Parameter populasi memegang peranan penting dalam pengkajian stok (Sparre \& Venema, 1999). Salah satu parameter yang utama adalah mengatur mortalitas akibat penangkapan (F). Salah satu upaya yang dapat dilakukan untuk mengelola sumberdaya ikan cakalang yang telah menunjukkan overfishing (penurunan ukuran ikan dan CPUE) di suatu area/wilayah adalah dengan cara melakukan pengaturan pemasangan rumpon dan moratorium pemasangan rumpon di area tertentu.

\section{KESIMPULAN}

Laju eksploitasi (E) ikan cakalang di Samudera Hindia Selatan Jawa dalam kondisi optimum dengan dugaan nilai laju eksploitasi sebesar 0,52/tahun. Mortalitas alami (M) ikan cakalang sebesar 1,44/tahun dan mortalitas akibat penangkapan $(F)$ sebesar 1,55/tahun dengan nilai mortalitas total sebesar 2,99/tahun. Ikan cakalang yang ditangkap sebagian belum matang gonad dengan nilai pertama kali ikan tertangkap $\left(\mathrm{L}_{\mathrm{c}}\right)$ sebesar 38,73 cmFL dan berada dibawah nilai pertama kali ikan matang gonad $\left(\mathrm{L}_{50}\right)$ sebesar 41-43 cmFL. Hal itu menunjukkan bahwa alat tangkap yang digunakan kurang selektif dalam menangkap ikan. Ikan cakalang di samudera Hindia Selatan Jawa ratarata berumur pendek dengan nilai koefisien pertumbuhan sebesar 1,100/tahun dan panjang asimptotik (L") sebesar $80,85 \mathrm{cmFL}$. Pertumbuhan cakalang dipengaruhi oleh kualitas air dan ketersediaan makanan alami yang melimpah. Pola rekrutmen dipengaruhi oleh musim pemijahan. Puncak rekrutment dan puncak pemijahan ikan cakalang terjadi pada bulan April dan Agustus.

\section{PERSANTUNAN}

Tulisan ini merupakan bagian dari hasil riset "Penelitian sumberdaya perikanan tuna skala kecil di Samudera Hindia selatan Jawa, Bali dan Nusa Tenggara" pada Loka Penelitian Perikanan Tuna Benoa. Penulis mengucapkan terima kasih kepada para enumerator dari Loka Penelitian Perikanan Tuna Benoa yang telah membantu mengumpulkan data perikanan cakalang pada tahun 2012.

\section{DAFTAR PUSTAKA}

Anonymous. 2012, Report of the fifteenth session of the scientific committee, IOTC-2012-SC15-R[E], Seychelles, 10-15 December 2012: 288p

Anonymous. 2014, Report of the sixteen session of the IOTC working party on tropical tuna, IOTC-2014WPTT16-R [E], Bali 15-19 November 2014: 105p
Anonymous. 2014, Report of the seventeenth session of the IOTC scientific committe, IOTC-SC17 2014, Seychelles 8-12 December 2014: 357 p

Anderson, R.O. \& Gutreuter. 1983. Length, weight and associated structural indices. In Nielsen, L.A. \& D.L Johnson, (Eds.): Fisheries Techniques, American Fisheries Society. Virginia: 289-298.

Andrade, H.A. \& C.A Garcia. 1999. Skipjack tuna fishery in relation to sea surface temperature off the southern Brazilian coast. Fish. Oceanogr. 8: 245-254

Arai, T., A. Kotake, S. Kayama, M. Ogura \& Y. Watanabe. 2005. Movements and life history patterns of the skipjack tuna (Katsuwonus pelamis) in the western Pacific, as revealed by otolith Sr: Ca ratios. J. Mar. Biol. Assoc. UK 85:1211-1216

Dueri, S., Faugeras, B., \& Maury, O. 2012. Modelling the skipjack tuna dynamic in the Indian Ocean with APECOSM-E: Part 1. Model Formulation. Ecological modeling 245 (2012): 41-54.

Effendie, M.I. 2002. Biologi Perikanan. Penerbit Yayasan Pustaka Nusatama, Yogyakarta: 163 halaman.

Fontenau, A. 2003. A comparative overview of skipjack fisheries and stocks worldwide. SCTB16 Working Paper: 11p.

Fontenau, A., \& D., Gascuel. 2008. Growth rates and apparent growth curves, for yellowfin, skipjack and bigeye tagged and recovered in the Indian Ocean during the IOTTP. IOTC-2008-WPTDA-08: 12p.

Gaertner, D., A.D. Molina, J. Ariz, R. Pianet and J.P. Hallier. 2008. Variability of the growth parametersof the skipjack tuna (Katsuwonus pelamis) among areas in the eastern Atlantic: analysis from tagging data within a meta-analysis approach. Aquat. Living Resour, 21:349-356.

Gayanilo, F.C. Jr., P. Sparre and D. Pauly. 2005. FAOICLARM stock assessment tool II (FiSAT II). Revised version. User's guide. FAO Computerized Information Series. (Fisheries).No.8. Revised version. FAO Rome: $168 \mathrm{p}$.

Gulland, J.A. 1971. The Fish Resources of the Oceans.FAO Fishing News (Books) Ltd. Surrey: 255p.

Hallier, J.P., \& D. Gaertner. 2006. Estimated growth rate of the skipjack tuna (Katsuwonus pelamis) from tagging surveys conducted in Senegalese area (1996-1999) within a meta-analysis framework. ICCAT, 59(2): 411-420p. 
Jamal, M., M. F. A. Sondita, J. Haluan \& B. Wiryawan. 2011. Pemanfaatan Data Biologi Ikan Cakalang (Katsuwonus pelamis) Dalam Rangka Pengelolaan Perikanan Bertanggung Jawab di Perairan Teluk Bone. Jurnal Natur Indonesia 14 (1), Oktober 2011: 107-113 hal.

Karman, A., Martasuganda, S., Sondita, M. F. A., \& Baskoro, M. S. 2013. Capture fishery biology of skipjack in western and southern water of North Maluku Province. International Journal of Science: Basic \& Applied Research (IJSBAR). 432-448.

King, M. 1995. Fisheries Biology: Assessment and Management. Fishing News Books. Oxford, England: 341p.

Mallawa, A., F. Amir \& M. Zainuddin. 2014. Keragaan biologi populasi ikan cakalang (Katsuwonus pelamis) yang tertangkap dengan purse seine pada musim timur di perairan laut Flores.Jurnal IPTEKS PSP, Vol 1 (2) Oktober 2014: 129-145.

Martono, Halimurrahman, R. Komarudin, Syarief, S. Priyanto \& D. Nugraha. 1997. Studi Variabilitas Lapisan Atas Perairan Samudera Hindia Berbasis Model Laut. Universitas Hang Tuah Surabaya.7 hal.

Mugo, R., Saitoh, S.-I., Nihira, A. \& Kuroyama, T., 2010. Habitat characteristics of skipjack tuna (Katsuwonus pelamis) in the western North Pacific: a remote sensing perspective. Fisheries Oceanography 19 (5), 382-396.

Nasution, S.H. 2009. Kajian dinamika populasi sebagai dasar pengelolaan ikan bonto-bonti (Paratherina striata) endemik di danau towuti, Sulawesi Selatan. Prosiding Seminar Nasional Forum Perairan Umum Indonesia VI, Palembang 18 November 2009. Balai Riset Perikanan Perairan Umum, Palembang: MSP 35 44.

Nihira, A. 1996. Studies on the behavioral ecology and physiology of migratory fish schools of skipjack tuna (Katsuwonus pelamis) in the oceanic frontal area. Bull. Tohoku Natl. Fish.Res. Inst. 58:137-23.
Nugraha B. \& E. Rahmat. 2008. Status Perikanan Huhate (Pole and Line) di Bitung, Sulawesi Utara. J.Lit. Perikan Ind. Pusat Riset Perikanan Tangkap. 14: 3 hal.

Ongkers, OTS. 2006. Pemantauan terhadap parameter populasi ikan teri merah (Encrasicholina heteroloba) di Teluk Ambon bagian dalam. Prosiding Seminar Nasional Ikan IV di Jatiluhur tanggal 29-30 Agustus 2006. Masyarakat Iktiologi Indonesia kerjasama dengan Loka Riset Pemacuan Stok Ikan, PRPT-DKP, Departemen MSP-IPB, dan Puslit BiologiLIPI: 31-40.

Pauly, D. 1983. Some Simple Methods for the Assessment of Tropical Fish Stocks. FAO Fisheries Technical Paper (254): 52p.

Pauly, D. 1987. A Review of the ELEFAN system for analysis of length-frequency data in fisland aquatic invertebrates. In length-based methods in fisheries research. ICLARM Conference Proceedings 13: 468p.

Sparre, P. \& Venema, S. 1999. Introduction to Tropical Fish Stock Assesment. (Introduksi Pengkajian Stok Ikan Tropis, alih bahasa: Pusat Penelitian dan Pengembangan Perikanan). Buku 1: Manual. Badan Penelitian dan Pengembangan Perikanan. Jakarta: 438 hal.

Stequert, B \& B. Ramcharrun. 1996. Reproduction of skipjack tuna (Katsuwonus pelamis) from the Western Indian Ocean. Aquatic Living Resources, 9: 235-247.

Uktolseja, J.C.B. 1989. The status of the Indonesian tuna fisheries.Report of the 3rd Southeast Asian Tuna Conference. Bali, Indonesia. 22 - 24 August, 1989. IPTPFAO: 66-81.

Welcomme, R. L. 2001. Inland Fisheries: Ecology and Management. London Fishing News Book.A Division of Blackwell Science: 358p 